\title{
Immobilization of Some Heavy Metals in Geopolymer Based on Water Treatment Sludge and Alum Industry Solid Waste
}

\author{
Ahmed Abdelaal ${ }^{1, *}$, Mohammed Abdelmawla ${ }^{1}$, Mokhtar S. Beheary ${ }^{1}$, Nabil A. Abdullah ${ }^{2}$, Taha \\ M. A. Razek ${ }^{3}$ \\ ${ }^{1}$ Environmental Sciences Department, Faculty of Science, Port Said University, Port Said, Egypt \\ ${ }^{2}$ R\&D Director Aluminum Sulfate Co. of Egypt \\ ${ }^{3}$ Institute of Environmental Studies and Researches, Ain Shams University, Cairo, Egypt \\ *Corresponding author: ahmed_abdelaal@sci.psu.edu.eg
}

\begin{abstract}
This paper investigates the immobilization behaviors of $\mathrm{Cd}^{2+}, \mathrm{Pb}^{2+}$ and $\mathrm{Hg}^{2+}$ ions in a geopolymer based on water treatment sludge (WTS) and dealuminated metakaolin (DaMK) solid waste from alum industry. For synthesis of WTS/DaMK based geopolymer, five mixes of WTS/DaMK (75/25, 80/20, 85/15, 90/10 and 95/5, respectively) are tested to obtain the optimum synthesis condition based on the compressive strength. Results showed that the geopolymer mortar with 85/15WTS/DaMK has the highest compressive strength (8 MPa). In addition, X-ray Diffraction (XRD) and X-ray Fluorescence (XRF) techniques are used to characterize the mineral and chemical compositions of WTS and DaMK. WTS/DaMK based geopolymer mortar have been tested for leaching to study its immobilization behavior under the optimum condition. The $\mathrm{Cd}^{2+}, \mathrm{Pb}^{2+}$ and $\mathrm{Hg}^{2+}$ ions were used and effectively immobilized in this study. The heavy metals with concentrations of 100, 200 and $300 \mathrm{ppm}$ were used in the geopolymer matrix giving about $98 \%$ of immobilization efficiency. The study showed that $\mathrm{Pb}^{2+}$ has the best immobilization efficiency followed by $\mathrm{Hg}^{2+}$ and $\mathrm{Cd}^{2+}$ with high concentrations.
\end{abstract}

\section{Keywords}

Geopolymer, dealuminated metakaolin, water treatment sludge, compressive strength, Heavy metals, immobilization.

\section{INTRODUCTION}

Geopolymer term has developed greatly in recent years as a new type of cementitious or binder material [1,2]. Geopolymer is distinguished from ordinary Portland cement by; production of cement requires higher calcining up to $1500^{\circ} \mathrm{C}$ in the rotary kiln, while geopolymer needs $600-800^{\circ} \mathrm{C}$; Portland cement emits $\mathrm{CO}_{2}$ more 10 times than geopolymer during the calcination; geopolymer resists chemicals and high temperatures giving good strength at room temperature, with excellent solidification of heavy metal ions [3, 4]. This make geopolymer with great properties in fields of civil, military engineering and environment like bridges, pavements, tiles, waste treatment, hydraulic, underground and insulators [5, 6]. 
Water treatment sludge (WTS) is generated as waste which required in conventional water treatment include disinfectant; clarification (coagulation, flocculation and sedimentation) and sand filtration are used to remove microorganisms, organic matter and suspended solids from surface water. Due to the cost of disposal and the prosecution by the Environmental Protection Agency, reusing water treatment sludge to manufacture ceramics and bricks has been considered as an eco-friendly alternative to landfills or drains [7, $8,9]$.

Dealuminated metakaolin (DaMK) is a byproduct of aluminum sulfate industry, the $\mathrm{SiO}_{2} / \mathrm{Al}_{2} \mathrm{O}_{3}$ ratio and B.E.T values are increased $[10,11]$. It is reported that DaMK shows an appreciable pozzolanic activity using isothermal calorimetric tests [12]. The investigation of DaMK confirmed presence of quartz and highly amorphous silica with a high surface area indicating high reactivity [13].

Millions of tons of waste including heavy metals from mine tailings, electroplating, dyeing and more industrial sludge are produced as waste each year worldwide. These wastes are accumulated in the ecosystem with a vast disposal issue. In general, $\mathrm{Cd}^{2+}, \mathrm{Pb}^{2+}$ and $\mathrm{Hg}^{2+}$ are common toxic metals [14]. Therefore, studies on the immobilization these metals are required for testing new solidification materials. $\mathrm{Pb}^{2+}, \mathrm{Hg}^{2+}$ and $\mathrm{Cd}^{2+}$ metal ions were participated in building of the geopolymer structure and can be adsorbed by the aluminium ions on the geopolymer skeleton. Based on this, the heavy metal immobilization is controlled by the adsorption mechanism and physical encapsulation according to the methodology in [15].

Previous studies were focused on geopolymers produced from metakaolin alone [16, 17, 18, 19] or wastes e.g., fly ash and slag [20,21, 22]. Some studies were focused on using WTS and DaMK as a waste immobilizing agent worldwide [21, 22, 23, 24, 25. 26]. However, WTS and DaMK contain much reactive $\mathrm{SiO}_{2}$ and $\mathrm{Al}_{2} \mathrm{O}_{3}$ that are suitable raw materials.

This study aims to produce a geopolymer mortar using WTS/DaMK and investigate its immobilization behaviour incorporating $\mathrm{Cd}^{2+}, \mathrm{Pb}^{2+}$ and $\mathrm{Hg}^{2+}$ ions as an eco-friendly approach for waste management and reducing the waste budget disposed into landfill and drains.

\section{MATERIALS AND METHODS}

\subsection{Materials}

WTS samples were collected from Sheikhzaied Water Treatment Plant located in sheikhzaied city, Giza, Egypt. The sludge consists of a ratio of alumina from the coagulation process in the Water Treatment Plant. Calcining temperature for preparing WTS was about $700^{\circ} \mathrm{C}$ for $1 \mathrm{~h}$. DaMK samples were obtained from the Egyptian Aluminum Sulfate Company (ASCE), Egypt. WTS and DaMK samples were grinded to fine powder, followed by grain size analysis. We used the grain size analysis to identify the grinding status of the studied wastes which is fine or course in order to keep the homogeneity of the mixes and to prevent presence of voids or cracks within the geopolymer mortar. Moreover, the compressive strength of geopolymer mortar relatively decreases with high grain size [27]. The chemical composition was obtained by XRF and the crystalline phases by XRD. The geopolymerization reaction between WTS/DaMK mixtures is occurred when $\mathrm{NaOH}$ is adding as a solution alkaline activator. However, the compressive strength is very important and a unique feature in identifying the solidification of geopolymers and cementitious materials [28]. $\mathrm{Cd}\left(\mathrm{NO}_{3}\right)_{2}, \mathrm{~Pb}\left(\mathrm{NO}_{3}\right)_{2}$ and $\mathrm{Hg}\left(\mathrm{NO}_{3}\right)_{2}$ are used as heavy metal sources.

\subsection{Sample preparation}

\subsubsection{Synthesis of WTS/DAMK based geopolymer}


Five various batches of geopolymer are carried out in this study. Batch WTS/DaMK has different weight ratio from 75/25, 80/20, 85/15, 90/10 into 95/5 respectively. Oxides (in molar ratios) are optimized as $\mathrm{SiO}_{2} / \mathrm{Al}_{2} \mathrm{O}_{3}, \mathrm{Na}_{2} \mathrm{O} / \mathrm{Al}_{2} \mathrm{O}_{3}$ and $\mathrm{H}_{2} \mathrm{O} / \mathrm{Na}_{2} \mathrm{O}$, therefore batch ratios will be selected in the range that achieves around $\mathrm{SiO}_{2} / \mathrm{Al}_{2} \mathrm{O}_{3}=4.5$ to comply with previous studies in comparison to the influence on mechanical strength [29].

The WTS/DaMK batches are dry mixed for 5 minutes then water was added during mixing and $\mathrm{NaOH}$ is mixed for another 5 minutes and cooled to room temperature. Sand is added to WTS/DaMK and mixed together. The produced geopolymer is moulded in $(50 \mathrm{~mm} \times 50 \mathrm{~mm} \times 50 \mathrm{~mm})$ cubes for testing the compressive strength and vibrated for a half minute. A plastic film covers the top surface of moulds to eliminate the water evaporation. Samples are excavated and cured under room temperature after one day.

\subsubsection{Efficiency of WTS/DAMK immobilization}

Three heavy metal ions $\mathrm{Cd}^{2+}, \mathrm{Pb}^{2+}$ and $\mathrm{Hg}^{2+}$ are mixed with WTS/DaMK geopolymer as a solution of $\mathrm{Cd}\left(\mathrm{NO}_{3}\right)_{2}, \mathrm{~Pb}\left(\mathrm{NO}_{3}\right)_{2}$ and $\mathrm{Hg}\left(\mathrm{NO}_{3}\right)_{2}$ in water with concentrations of 100,200 and $300 \mathrm{ppm}$. Batch "WTS/DaMK-Cd100", "WTS/DaMK-Cd200" and "WTS/DaMK-Cd300" are utilized to study the immobilization efficiency of $\mathrm{Cd}^{2+}$ concentration, Batch "WTS/DaMK-Pb100", "WTS/DaMK-Pb200" and "WTS/DaMK-Pb300" are utilized to study the immobilization efficiency of $\mathrm{Pb}^{2+}$ concentration, and Batch "WTS/DaMK-Hg100", "WTS/DaMK-Hg200" and "WTS/DaMK-Hg300" are utilized to study the immobilization efficiency of $\mathrm{Hg}^{2+}$ concentration.

\subsection{Experiment and tests}

\subsubsection{Mechanical tests}

Compressive strengths of the WTS/DaMK geopolymer cubes were tested after 7 and 28 days of curing according to the ASTM C109 Method [30, 31]. The compressive test was carried out using NonAutomatic Compression Range 200 KN-Hoek Cell Machine in the Material Test Laboratory at National Research Centre (NRC), Cairo, Egypt.

\subsubsection{Leaching tests}

Leaching test using Toxicity Characteristic Leaching Procedure (TCLP) is carried out in this study $[21,32,33]$. The TCLP test is carried out according to [21]. We extracted samples at one, two, three, four, twenty and twenty-four hours. These samples were analysed for heavy metals using ICP-AES in the Reference Laboratory of Drinking Water at the Egyptian Holding Co. Water and Wastewater (HCWW), Cairo, Egypt.

\section{RESULTS AND DISCUSSION}

The particle size distribution of WTS and DaMK samples is shown in Fig. 1, indicating that WTS particles are irregular in shape within a range of $680-1511.7 \mathrm{~nm}$ with a mean of $1115.3 \mathrm{~nm}$. DaMK particles are slightly finer and spherical within a range of $188-514 \mathrm{~nm}$ with a mean of $366 \mathrm{~nm}$. The analysis shows that $25 \%$ from WTS particles are closely like $80 \%$ of DaMK [34]. 

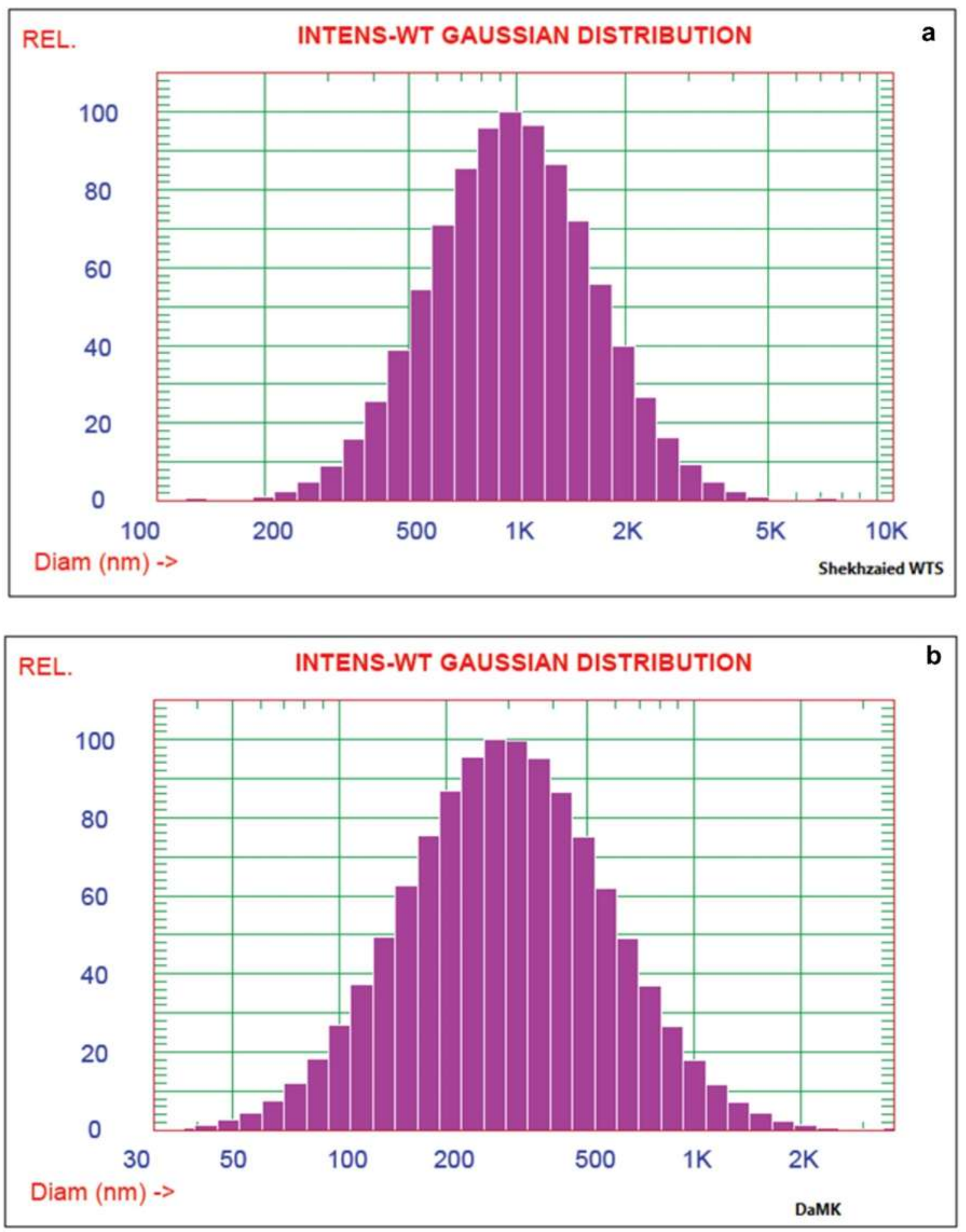

Figure (1): Particle size distribution of WTS (a) and DAMK (b).

The value of specific gravity of aggregate and filler is very important in determining the quantity, which required in the mix proportioning. The specific gravity of sand, which used in this study, is 2.35 and carried out using laboratory tests [35, 36].

The WTS sludge consists of a ratio of alumina from the coagulation process in the Water Treatment Plant, and then it was calcined at $700^{\circ} \mathrm{C}$ for $1 \mathrm{~h}$ in mafle furnace at $\mathrm{HCWW}$. While, kaolinite is the raw material in the manufacture of MK and DaMK after several successive operations that are carrying out in 
the ASCE, where kaolinite is cracked, grinded and then calcined at $700^{\circ} \mathrm{C}$ for two hours to form $\mathrm{MK}$, then react with concentrated sulfuric acid to extract alumina and forming DaMK [37]. The mineral characteristics of WTS and DaMK samples are determined by XRD and shown in Fig. 2. The analysis shows that WTS samples consist of mainly halo humps with peaks of minor crystalline inclusions of hatrurite, chloromagnesite and quartz (Fig. 2a). While DaMK samples consist of amorphous humps with peaks of mineral components of quartz, anatase and sillimanite (Fig. 2b).
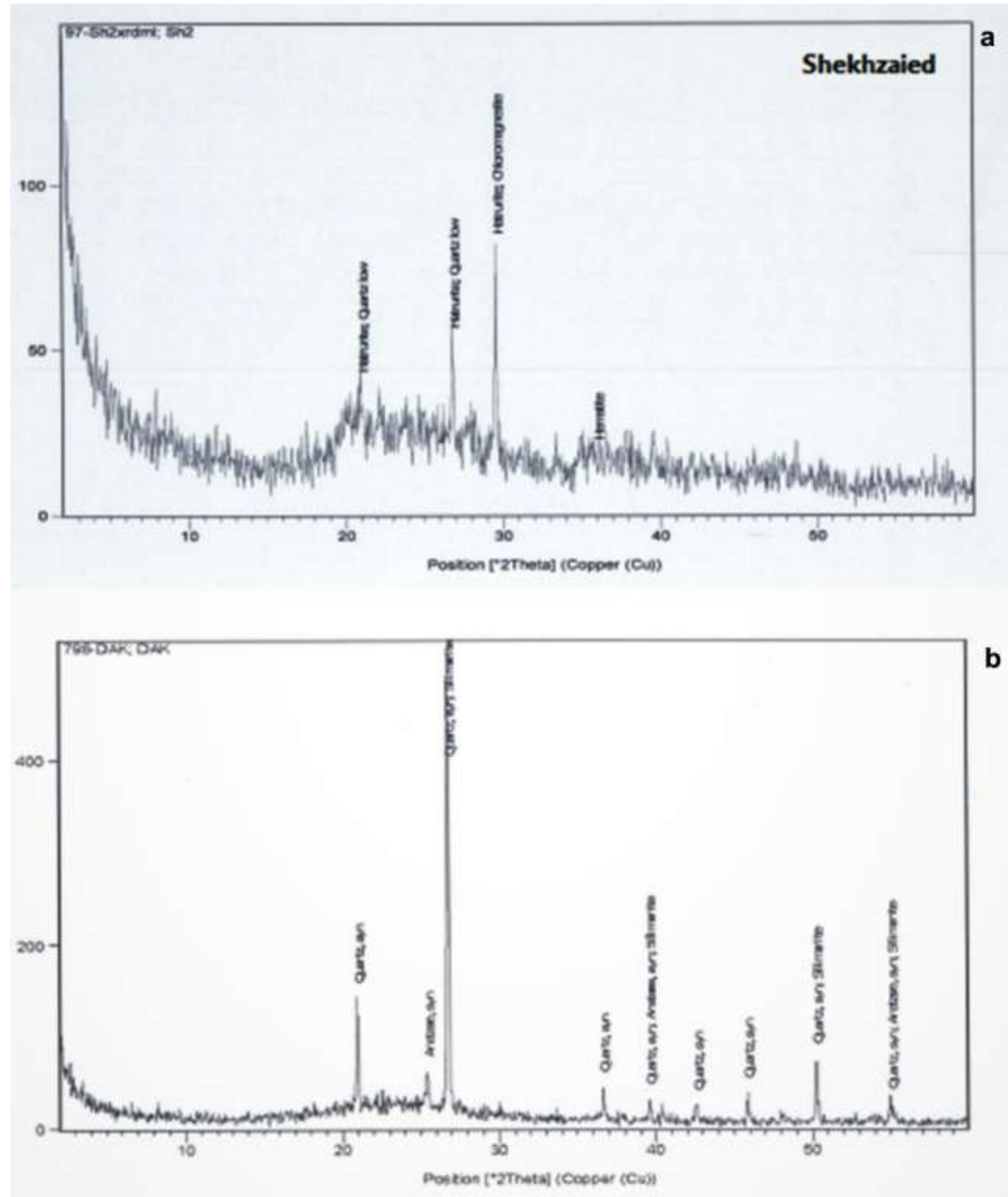

Figure (2): XRD patterns of WTS (a) and DaMK (b). 
Table 1 shows the chemical criteria of WTS (dried at $105^{\circ} \mathrm{C}$ and calcined at $700^{\circ} \mathrm{C}$ ) and DaMK samples which determined by XRF analysis to check whether the materials are a pozzolan and if it can be used in production of geopolymer mortar. The analysis shows the percentages of major components $\left(\mathrm{SiO}_{2}\right.$, $\mathrm{Al}_{2} \mathrm{O}_{3}$ and $\mathrm{Fe}_{2} \mathrm{O}_{3}$ ) in WTS105 are 58.36\% while $\mathrm{CaO}$ and $\mathrm{SO}_{3}$ contents are $5.46 \%$ and $1.92 \%$. After calcinations at $700^{\circ} \mathrm{C}$, the crystalline components (e.g., hatrurite, chloromagnesite and quartz) were discarded between its folds. Major components of WTS700 $\left(\mathrm{SiO}_{2}, \mathrm{Al}_{2} \mathrm{O}_{3}\right.$ and $\left.\mathrm{Fe}_{2} \mathrm{O}_{3}\right)$ are $69.71 \%$, while in DaMK are $\mathrm{SiO}_{2}(82.83 \%)$ and $\mathrm{Al}_{2} \mathrm{O}_{3}(6 \%)$. Accordingly, WTS/DaMK can be used as a pozzolanic material [38].

Table (1): Chemical composition of WTS and DaMK (WT\%).

\begin{tabular}{|c|c|c|c|}
\hline Oxides & WTS $105^{\circ} \mathrm{C}$ & WTS $700^{\circ} \mathrm{C}$ & DaMK \\
\hline $\mathrm{SiO}_{2}$ & 40.35 & 45.72 & 82.83 \\
\hline $\mathrm{Al}_{2} \mathrm{O}_{3}$ & 14.88 & 19.18 & 6.00 \\
\hline $\mathrm{Fe}_{2} \mathrm{O}_{3}$ & 3.13 & 4.81 & 0.50 \\
\hline $\mathrm{CaO}$ & 5.46 & 6.8 & 0.15 \\
\hline $\mathrm{Na}_{2} \mathrm{O}$ & 0.32 & 0.2 & 0.03 \\
\hline $\mathbf{K}_{2} \mathbf{O}$ & 0.52 & 0.58 & 0.05 \\
\hline $\mathrm{TiO}_{2}$ & 0.44 & 0.52 & 3.4 \\
\hline MgO & 0.81 & 0.86 & 0.09 \\
\hline MnO & 0.28 & 0.42 & 0.01 \\
\hline $\mathrm{SO}_{3}$ & 1.92 & 1.16 & 0.85 \\
\hline $\mathbf{P}_{2} \mathbf{O}_{5}$ & 0.16 & 0.3 & 0.01 \\
\hline $\mathrm{Cl}^{-}$ & 4.67 & 4.83 & 0.06 \\
\hline Loss of Ignition (L.O.I) & 26.76 & 14.26 & 5.84 \\
\hline Total & 99.7 & 99.64 & 99.82 \\
\hline Molar ratio of $\mathrm{SiO}_{2} / \mathrm{Al}_{2} \mathrm{O}_{3}$ & 4.62 & 4 & 23 \\
\hline
\end{tabular}

\subsection{Synthesis of WTS/DaMK based geopolymer}

In order to study the influence of WTS/DAMK ratio, batches are prepared 75/25, 80/20, 85/15, 90/10 and 95/5 as percentage by mass, respectively. These ratios were chosen to be close to the most suitable ratios of the $\mathrm{SiO}_{2} / \mathrm{Al}_{2} \mathrm{O}_{3}$ used in forming geopolymer in literature. Many studies deal the ratio between $\mathrm{SiO}_{2} / \mathrm{Al}_{2} \mathrm{O}_{3}$ which varies from 3 to 5.5, and the ratio between $\mathrm{Na}_{2} \mathrm{O} / \mathrm{Al}_{2} \mathrm{O}_{3}$ varies from 0.8 to 1.2. While the ratio between $\mathrm{H}_{2} \mathrm{O} / \mathrm{Na}_{2} \mathrm{O}$ ranges from 10 to 14 in some cases according to the potency of each compound at the crystalline state. These ratios were calculated based on the measurements presented in Table 1 and reported in Table 2. The compressive strength of WTS/DAMK geopolymers are illustrated in Fig. 3.

Non-calcined WTS cannot achieve a compressive strength because quartz and crystalline $\mathrm{SiO}_{2}$ in WTS105 do not develop a geopolymer reaction. Abdelmawla et al. (2019) reported that WTS105 was used as filler only [28]; however, in this study WTS was calcined at $700^{\circ} \mathrm{C}$ for $1 \mathrm{~h}$ with recrystallization and converting the crystalline structure to amorphous oxides that can be calculated in the ratio between $\mathrm{SiO}_{2} / \mathrm{Al}_{2} \mathrm{O}_{3}$ to distinguish the geopolymerization reaction. WTS700/DaMK85/15 achieves a compressive strength of $8 \mathrm{MPa}$ at 28 days (Fig. 3), although is lower than geopolymers from other aluminosilicate sources [39]. 
Table (2): Batches of WTS/DaMK based geopolymer with different mixes.

\begin{tabular}{|c|c|c|c|c|}
\hline Types of geopolymer & $\mathrm{SiO}_{2} / \mathrm{Al}_{2} \mathrm{O}_{3}$ & $\mathrm{Na}_{2} \mathrm{O} / \mathrm{Al}_{2} \mathrm{O}_{3}$ & $\mathrm{H}_{2} \mathrm{O} / \mathrm{Na}_{2} \mathrm{O}$ & $\begin{array}{c}\text { Binder: Sand } \\
\text { (by mass) }\end{array}$ \\
\hline WTS/DaMK 75/25 & 5.89 & 1.24 & \multirow{5}{*}{14.3} & $1: 1$ \\
\hline WTS/DaMK 80/20 & 5.39 & 1.17 & & $1: 1$ \\
\hline WTS/DaMK 85/15 & 5.06 & 1.15 & & $1: 1$ \\
\hline WTS/DaMK 90/10 & 4.70 & 1.11 & & $1: 1$ \\
\hline WTS/DaMK 95/5 & 4.37 & 1.07 & & $1: 1$ \\
\hline
\end{tabular}

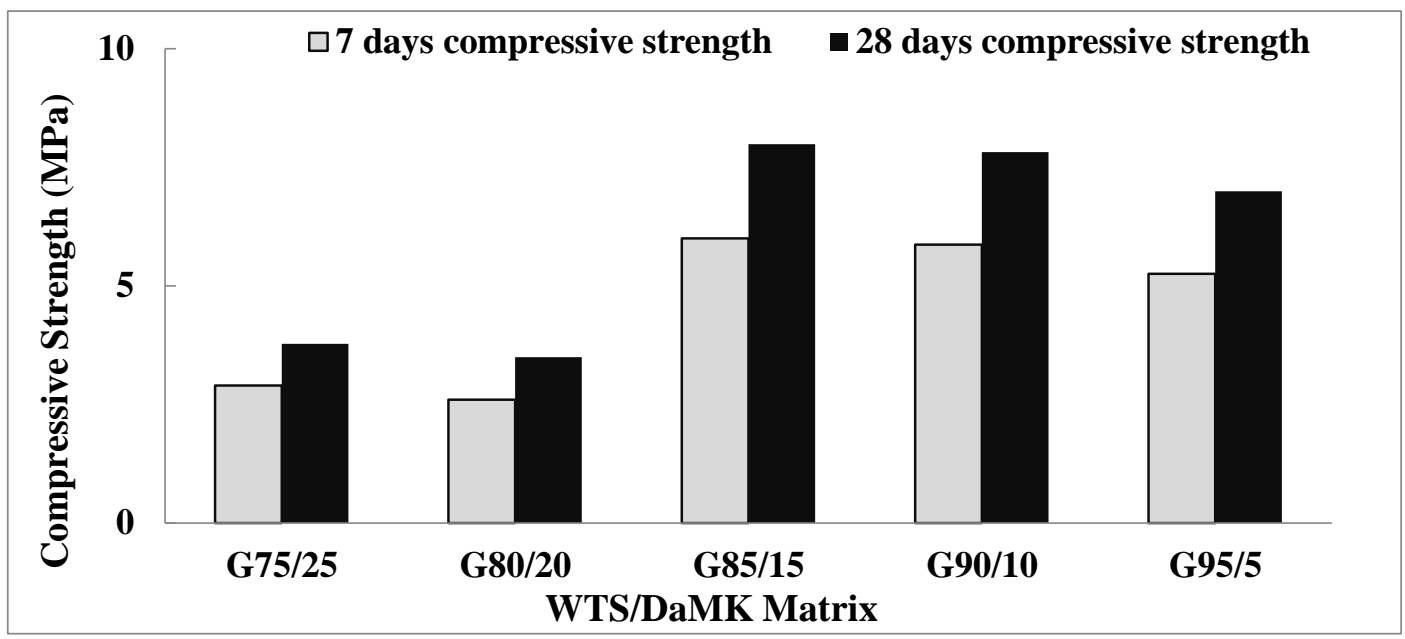

Figure (3): Compressive strengths of WTS/DAMK based geopolymers.

\subsection{Efficiency of WTS/DAMK immobilization}

The compressive strengths of WTS/DAMK geopolymer (WTS700/DaMK85/15) containing various kinds and concentrations of heavy metals were studied and shown in Table 3. A slight reduction in compressive strength is observed when a heavy metal with a concentration of $300 \mathrm{ppm}$ or less mixed with WTS700/DaMK85/15 geopolymer. Moreover, increased concentration of heavy metals must be calculated to maintain the available strength $[23,24,40]$.

Table (3): Batches of WTS/DaMK with different mixes.

\begin{tabular}{|c|c|c|c|}
\hline Geopolymer matrix & $\begin{array}{c}\text { Heavy metal } \\
\text { content }(\mathbf{p p m})\end{array}$ & $\begin{array}{c}\text { Compressive } \\
\text { strength (MPa) }\end{array}$ & $\begin{array}{c}\text { Immobilization } \\
\text { Efficiency (\%) }\end{array}$ \\
\hline \multirow{4}{*}{ WTS700/DaMK85/15 } & -- & 8 & -- \\
\cline { 2 - 4 } & $\mathrm{Cd} 100$ & 7.81 & 98.83 \\
\cline { 2 - 4 } & $\mathrm{Cd} 200$ & 7.51 & 98.56 \\
\cline { 2 - 4 } & $\mathrm{Cd} 300$ & 7.09 & 97.82 \\
\cline { 2 - 4 } & $\mathrm{Pb} \mathrm{100}$ & 7.72 & 99.57 \\
\cline { 2 - 4 } & $\mathrm{Pb} 200$ & 7.75 & 99.48 \\
\cline { 2 - 4 } & $\mathrm{Pb} 300$ & 7.47 & 98.93 \\
\cline { 2 - 4 } & $\mathrm{Hg} 100$ & 7.76 & 99.43 \\
\cline { 2 - 4 } & $\mathrm{Hg} 200$ & 7.63 & 98.92 \\
\cline { 2 - 4 } & $\mathrm{Hg} \mathrm{300}$ & 7.28 & \\
\hline
\end{tabular}


Batch "WTS700/DAMK85/15-Cd100" to Batch "WTS700/DaMK85/15-Cd300", Batch "WTS700/DaMK85/15-Pb100" to Batch "WTS700/DaMK85/15-Pb300" and Batch "WTS700/DaMK85/15-Hg100" to Batch "WTS700/DaMK85/15-Hg300" incorporating same type and different concentrations of heavy metals. Accordingly, leaching results can be used to distinguish the influence of type of heavy metal ions on the immobilization behaviors on the same basis. The immobilization efficiencies for each batch were measured and reported in Table 3 based on the results in Fig. 4.
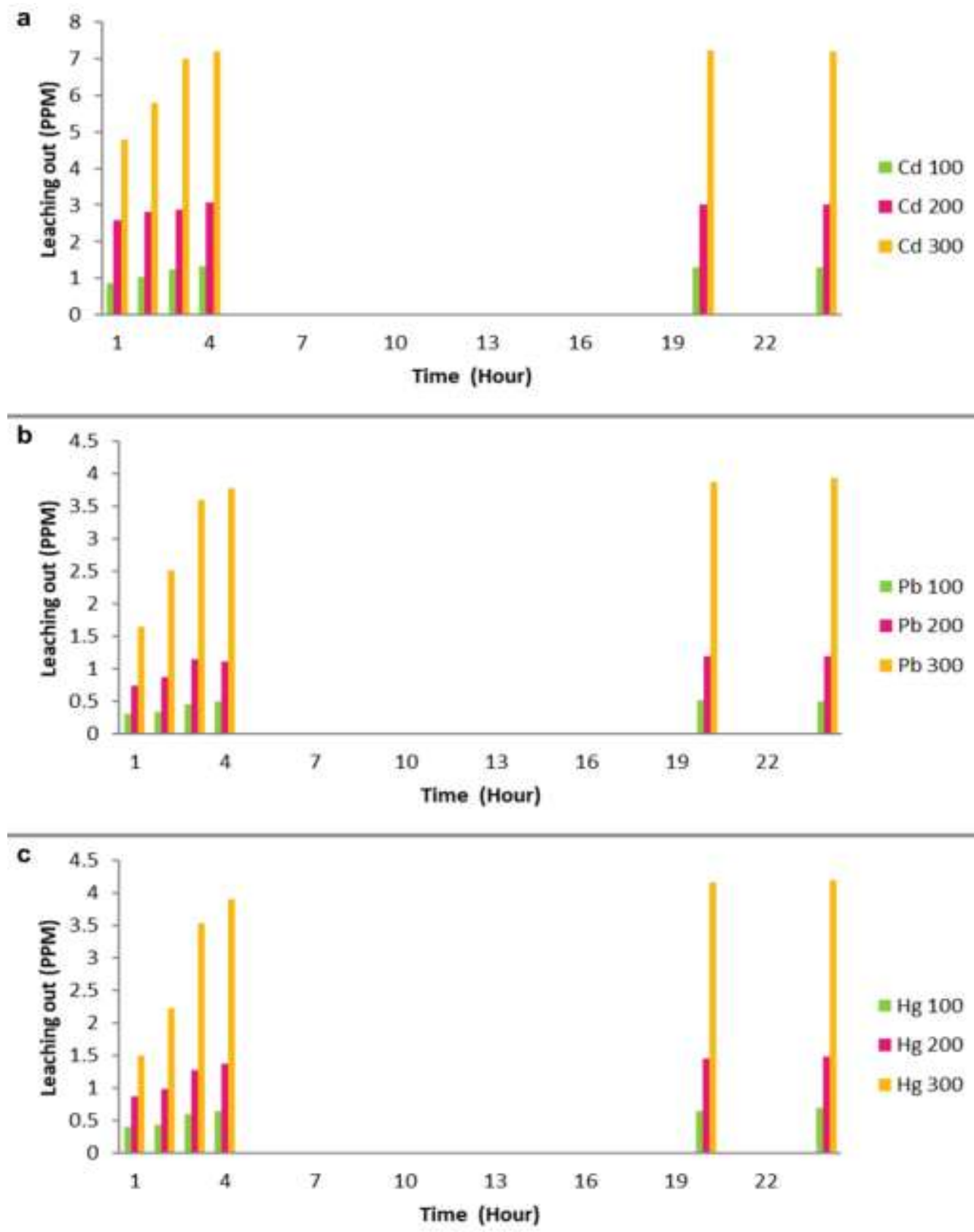

Figure (4): Kinetic leaching curve of WTS/DaMK based geopolymer containing different amounts of $\mathrm{Cd}^{2+}$ (a), $\mathrm{Pb}^{2+}$ (b) and $\mathrm{Hg}^{2+}$ (c).

Leaching of heavy metals started within WTS/DaMK geopolymer with initial concentrations then slightly increased until reaching the equilibrium at four hours (Fig. 4). The WTS/DaMK geopolymer 
showed high efficiencies with low concentrations e.g., 200 ppm or less, giving negligible concentrations. Therefore, the immobilization efficiency reaches more than $98 \%$ (Table 3). The immobilization efficiencies were quickly reduced with adding high heavy metal concentrations (e.g. $300 \mathrm{ppm}$ of $\mathrm{Cd}^{2+}$ ) which is matching with the compressive strength of same samples in Table 3. We noticed in WTS/DaMK geopolymer matrix that $\mathrm{Pb}^{2+}$ and $\mathrm{Hg}^{2+}$ ions were leached less than $\mathrm{Cd}^{2+}$ in heavy metals with high concentrations regardless the leaching time (Fig. 4).This can be referred to the variability in atomic mass in $\mathrm{Pb}^{2+}(207.2 \mathrm{u}), \mathrm{Hg}^{2+}(200.59 \mathrm{u})$ and $\mathrm{Cd}^{2+}(112.41 \mathrm{u})[21]$.

\section{CONCLUSION}

In this paper, two wastes from water treatment sludge and aluminium sulphate industry were used to produce Geopolymer mortar which consists $85 \%$ from calcined WTS $\left(700^{\circ} \mathrm{C}\right.$ at $\left.1 \mathrm{~h}\right)$ with $15 \%$ DaMK achieved a compressive strength of $8 \mathrm{MPa}$.

Leaching tests showed that the WTS/DaMK geopolymer has a powerful immobilization efficiency of heavy metals $\mathrm{Cd}^{2+}, \mathrm{Pb}^{2+}$ and $\mathrm{Hg}^{2+}$. The efficiencies reach $98 \%$ of heavy metals, incorporated within the WTS/DaMK geopolymer matrix, that have concentrations of 100, 200 and 300 ppm by mass of binders.

We noticed that $\mathrm{Pb}^{2+}$ shows a better efficiency of immobilization than $\mathrm{Hg}^{2+}$ and $\mathrm{Cd}^{2+}$ in case of heavy metals with high concentrations. This can be referred to differences in atomic mass and the chemical interaction with the WTS/DaMK geopolymer matrix.

\section{REFERENCES}

[1] DAVIDOVITS, J. Geopolymers and geopolymeric materials. Journal of Thermal Analysis and Calorimetry, 35(2), 429-441, 1989.

[2] DAVIDOVITS, J., DAVIDOVICS, M. Geopolymer: ultra-high temperature tooling material for the manufacture of advanced composites. How Concept Becomes Reality, 36, 1939-1949, 1991.

[3] DAVIDOVITS, J. Properties of geopolymer cements. First international conference on alkaline cements and concretes, 1, 131-149. Kiev State Technical University, Ukraine: Scientific Research Institute on Binders and Materials, 1994.

[4] LYON, R. E., BALAGURU, P. N., FODEN, A., SORATHIA, U., DAVIDOVITS, J., DAVIDOVICS, M. Fire-resistant aluminosilicate composites. Fire and materials, 21(2), 67-73, 1997.

[5] MONALDO, E., NERILLI, F. AND VAIRO, G. Basalt-based fiber-reinforced materials and structural applications in civil engineering. Composite Structures, 214, 246-263, 2019.

[6] PATHAK, A. A laboratory scale synthesis of geopolymer from construction wastes ( $\mathrm{PhD}$ thesis). Institute of Science and Technology, Central Department of Chemistry, Tribhuvan University, Nepal, 2016.

[7] CHIANG, K. Y., CHOU, P. H., HUA, C. R., CHIEN, K. L., CHEESEMAN, C. Lightweight bricks manufactured from water treatment sludge and rice husks. Journal of hazardous materials, 171(1-3), 76-82, 2009.

[8] RODRÍGUEZ, N. H., RAMÍREZ, S. M., VARELA, M. B., GUILLEM, M., PUIG, J., LARROTCHA, E., FLORES, J. Re-use of drinking water treatment plant (DWTP) sludge: characterization and technological behaviour of cement mortars with atomized sludge additions. Cement and Concrete Research, 40(5), 778-786, 2010.

[9] TEIXEIRA, S. R., SANTOS, G. T. A., SOUZA, A. E., AlESSIO, P., SOUZA, S. A., SOUZA, N. R. The effect of incorporation of a Brazilian water treatment plant sludge on the properties of ceramic materials. Applied Clay Science, 53(4), 561-565, 2011. 
[10] MOHAMED, M. A., KASSIM, M. E., EL-KATATNY, E. A. Optimization of the extraction of aluminum sulfate and ammonium aluminum sulfate alums from aluminum dross tailings. Journal of materials research, 13(4), 1075-1083, 1998.

[11] ADEREMI, B. O., EDOMWONYI-OTU, L., ADEFILA, S. S. A new approach to metakaolin dealumination. Australian Journal of Basic and Applied Sciences, 3(3), 2243-2248, 2009.

[12] MOSTAFA, N. Y., EL-HEMALY, S. A. S., AL-WAKEEL, E. I., EL-KORASHY, S. A., BROWN, P. W. Characterization and evaluation of the pozzolanic activity of Egyptian industrial by-products: I: Silica fume and dealuminated kaolin. Cement and Concrete Research, 31(3), 467-474, 2001.

[13] NIGUSSIE, W., ZEWGE, F., CHANDRAVANSHI, B. S. Removal of excess fluoride from water using waste residue from alum manufacturing process. Journal of Hazardous Materials, 147(3), 954963, 2007.

[14] SÁNCHEZ-CHARDI, A. Biomonitoring potential of five sympatric Tillandsia species for evaluating urban metal pollution ( $\mathrm{Cd}, \mathrm{Hg}$ and $\mathrm{Pb})$. Atmospheric Environment, 131, 352-359, 2016.

[15] GUO, B., LIU, B., YANG, J. AND ZHANG, S. The mechanisms of heavy metal immobilization by cementitious material treatments and thermal treatments: A review. Journal of environmental management, 193, 410-422, 2017.

[16] DAVIDOVITS, J., DAVIDOVITS, J. Method for obtaining a geopolymeric binder allowing to stabilize, solidify and consolidate toxic or waste materials. U.S. Patent 5 (539), 140, 1996.

[17] DAVIDOVITS, J., COMRIE, D. C., PATERSON, J. H., RITCEY, D. J. Geopolymeric concretes for environmental protection. Concrete International, 12(7), 30-40, 1990.

[18] COMRIE, D. C., DAVIDOVITS, J. Waste containment technology for management of uranium mill tailings. In Proceedings of the 117th Annual Meeting of the Society of Mining Engineers, Phoenix, AZ, USA, January 1988.

[19] LIEW, Y. M., HEAH, C. Y., KAMARUDIN, H. Structure and properties of clay-based geopolymer cements: A review. Progress in Materials Science, 83, 595-629, 2016.

[20] PROVIS, J. L., VAN DEVENTER, J. S. J. EDS. Geopolymers: structures, processing, properties and industrial applications, 2009, Elsevier.

[21] YUNSHENG, Z., WEI, S., QIANLI, C., LIN, C. Synthesis and heavy metal immobilization behaviors of slag based geopolymer. Journal of hazardous materials, 143(1-2), 206-213, 2007.

[22] ZHANG, J., PROVIS, J. L., FENG, D., VAN DEVENTER, J. S. Geopolymers for immobilization of Cr6+, Cd2+, and Pb2+. Journal of Hazardous Materials, 157(2-3), 587-598, 2008.

[23] ASHMAWY, A.M., IBRAHIM, H.S., MONIEM, S.M.A. AND SALEH, T.S. Immobilization of some metals in contaminated sludge by zeolite prepared from local materials. Toxicological \& Environmental Chemistry, 94(9), 1657-1669, 2012.

[24] LASHEEN, M.R., ASHMAWY, A.M., IBRAHIM, H.S. AND MONIEM, S.M.A. Pozzolanic-based materials for stabilization/solidification of contaminated sludge with hazardous heavy metal: case study. Desalination and Water Treatment, 51(13-15), 2644-2655, 2013.

[25] AYDIN, A.A. AND AYDIN, A. Development of an immobilization process for heavy metal containing galvanic solid wastes by use of sodium silicate and sodium tetraborate. Journal of hazardous materials, 270, 35-44, 2014.

[26] TANTAWY, M.A., AHMED, S.A., ABDALLA, E.M. AND QASSIM, M.I. Immobilization of copper ions laden kaolin waste: influence of thermal treatment on its immobilization in cement paste. Journal of Material Cycles and Waste Management, 18(2), 263-272, 2016.

[27] ASSI, L.N., DEAVER, E.E. AND ZIEHL, P. Effect of source and particle size distribution on the mechanical and microstructural properties of fly Ash-Based geopolymer concrete. Construction and Building Materials, 167, 372-380, 2018. 
[28] ABDelmawla, M., AbDelaAl, A., BehEARY, M. S., ABDUllah, N. A., RAZEK, T. M. Compressive Strength of Geopolymeric Cubes Produced from Solid Wastes of Alum Industry and Drinking Water Treatment Plants, Egtpt. J. Chem. 62 (12), 2331-2340, 2019.

[29] YUNSHENG, Z., WEI, S., ZONGJIN, L. Impact behavior and microstructural characteristics of PVA fiber reinforced fly ash-geopolymer boards prepared by extrusion technique. Journal of materials science, 41(10), 2787-2794, 2006.

[30] KRISHNAN, P., JEGALAKSHIMI J., JEGALAKSHIMI, J. "Recovery of Water Treatment Residue into Clay Bricks. Chemical Engineering Transactions 56 (2011), 1837-42, 2017.

[31] ASTM C109/109M-16A. Standard Test Method for Compressive Strength of Hydraulic Cement Mortars (Using 2-in. or Cube Specimens). Annual Book of ASTM Standards, 2016.

[32] VAN JAARSVELD, J. G. S., VAN DEVENTER, J. S. J., LORENZEN, L. Factors affecting the immobilization of metals in geopolymerized flyash. Metallurgical and materials transactions, 29(1), 283-291, 1998.

[33] SCOTT, J., BEYDOUN, D., AMAL, R., LOW, G., CATTLE, J. Landfill management, leachate generation, and leach testing of solid wastes in Australia and overseas. Critical Reviews in Environmental Science and Technology, 35(3), 239-332, 2005.

[34] KENNE DIFFO, B. B., ElimBI, A., CYR, M., DIKA MANGA, J., TCHAKOUTE KOUAMO, H. Effect of the rate of calcination of kaolin on the properties of metakaolin-based geopolymers. Journal of Asian Ceramic Societies, 3(1), 130-138, 2015.

[35] PAN, Z., SANJAYAN, J. G., KONG, D. L. Effect of aggregate size on spalling of geopolymer and Portland cement concretes subjected to elevated temperatures. Construction and Building Materials, 36, 365-372, 2012.

[36] CHAKRAVORTY, A., KHATRI, R., TEJKUVARBA, PARMAR, A. Effect of aggregate size and silica fume on the workability of geopolymer concrete. Int. J. Res. Eng. Technology, 3 (4), 2014. http://refhub.elsevier.com/S0169-1317(17)30261-2/rf0030.

[37] DAS, B. R., DASH, B., TRIPATHY, B. C., BHATTACHARYA, I. N., DAS, S. C. Production of $\eta-$ alumina from waste aluminium dross. Minerals Engineering, 20(3), 252-258, 2007.

[38] SZAREK, Ł., WOJTKOWSKA, M. Properties of fly ash from thermal treatment of municipal sewage sludge in terms of EN 450-1. Archives of Environmental Protection, 44, 2018.

[39] ZHANG, B., MACKENZIE, K. J., BROWN, I. W. Crystalline phase formation in metakaolinite geopolymers activated with $\mathrm{NaOH}$ and sodium silicate. Journal of materials science, 44(17), 46684676, 2009.

[40] LASHEEN, M.R., ASHMAWY, A.M., IBRAHIM, H.S. AND MONIEM, S.M.A. Immobilization technologies for the management of hazardous industrial waste using granite waste (case study). Korean Journal of Chemical Engineering, 33(3), 914-921, 2016. 